\title{
English Language Textbooks in EFL Education: Do They Improve Students' National, International and Target Culture Familiarity?
}

\author{
Reza Abbasian \\ Islamic Azad University, Izeh Branch, Khuzestan, Iran \\ Reza Biria \\ Islamic Azad University, Isfahan (Khorasgan) Branch, Isfahan, Iran
}

\section{Introduction}

Now, English is the most widely spoken language in the world. Due to its wide spread distribution, it has been used for different means such as business, education, travel, and science. In addition, societies all around the world have to learn English to reach their different goals. However, a controversial question emerges whether to teach 'culture' along with English or not. Teaching 'culture' along with English has been consideredby some researchers from different perspectives such as applied linguistics and sociolinguistics in the last two decades. There exist four views regarding this issue. The first one maintains that 'target language culture' should be learned along with English to acculturate language learners into the cultures of English speaking countries (Byram, 1990; Byram\&Flemming, 1998). The second one states that any teaching of the 'target language culture' should not accompany with English in the countries where English is a second language (Kachru, 1985, 1986; Kachru\& Nelson, 1996; Canagarajah, 1999). The other two perspectives also discard the idea of teaching 'target language culture' along with English. Nevertheless, one of them supports the teaching of 'target culture' in English language teaching (Kramsch\& Sullivan, 1996; McKay, 2003), the other view holds that English transforms to lingua franca and it should be learned in a culture-free context (Alptekin, 2005; Jenkins, 1996, 2000,2002,2005;Seidlhofer,2001). 


\section{1 Culture}

Many different meanings can be interpreted by the word culture. For some people it relates to good art, music, literature, and food. Anthropologists and other behavioral scientists believe that culture is the full range of learned human behavior patterns. The word "culture" was first used by one of the first English Anthropologist Edward B. Tylor in his book, Primitive Culture, published in 1871. Tylor states that culture is "that complex whole which includes knowledge, ideas, art, law, morals, custom, and any other capabilities and habits learned by human as a member in a society." Of course, it is not constrainedto men. Women have it as well. In Tylor's time, culture attracted the central focus of anthropology because itwasa delicate phenomenon and influential human tool for survival. It is permanentlyvarying and easily shifts because it exists only in our minds. In fact, our language skills, administrations, constructions, and other artificial things are merely the products of culture. They are not culture by themselves. They echo cultural patterns that were made and used via cultural knowledge and skillfulness. In other meanings, culture is anattribute of a specific group of people, characterized by everything from religion, language social customs, cuisine, music and arts. Culture is the only thing that makes countries unique. Every country possesses different cultural events and cultural ceremonies. Cultures are more than just material that the cultures consume and produce. Culture is also the opinions and morals of the people, and embraces the way people contemplate about and conceive the world and their own lives. Culture can also differ within a district, region, and society. A workstation may have a particular culture that makes it apart from comparable work stations. A district of a country may have different culture and sub culture from the rest of the country. For example, Iran's east region has a different culture from the rest of the country, which is expressed by different ways of talking, different types of music, and different types of clothing. Even a family may possess a specific set of values and norms because they follow their own religion.

\section{2 Importance of culture in language teaching}

According to Wei (2005, p. 56), language possesses dual character: one as a means of communication and the other as a transferor of culture. Language without culture is impossible, human culture without language is too. A specific language is a mirror image of a particular culture. Brown (1994, p. 165) defines the relationship between language and culture as follows: 'A language is a part of a culture and a culture is a part of a language; the two are complicatedly intertwined, so one cannot separate the two without losing the importance of either language or culture'. To sum up the point, culture and language are always together (cited in 
Jiang, 2000, p. 328). When it comes to the field of teaching and learning, as Gao (2006, p. 59) states it, the interdependence of language learning and cultural learning is so vivid that one can infer that language learning is culture learning and accordingly, language teaching is cultural teaching. Gao further expresses that foreign language teachers should be aware of cultural studies of the place in which foreign language classroom is heldand attempt to augment students' cultural awareness and develop their communication competence. Wang (2008) alsostates that 'foreign language teaching is teaching of foreign culture, and foreign language teacher is foreign culture teacher'. Tomalin (2008) considers the international role of the English language and globalization as the two main causes to teach culture as a fifth language skill, apart from listening, speaking, reading and writing. The fifth language skill teaches you the outlook, belief and technique to adjust your use of English to learn about, comprehend and raise the value of ones' society, ways of performance and distinctive qualities of other cultures. It encompasses understanding how to practice language to accept differences, to be ductile and lenient with ways of performance which might be individual specific. It is a conceptual change that is conveyed through the use of language.' Tomalin (2008) states that teaching of culture in ELT classes should take account of cultural knowledge, cultural values (the 'psyche' of the country), what people believe that is important, cultural behavior, and cultural skills, using English language as a means of communication.

Based on the above-mentioned points, the inclusion of the cultural elements in EFL syllabus is necessary for some reasons. Primarily, the application of EFL education in syllabus will be under a big question since effective communication with foreigners requires mutual understanding of cultural aspects to some extent. Additionally, absence of national and international cultural elements in EFL textbooks may lead to some misunderstandings in communication, and also familiarity with the sociopragmatic aspects of language, that is a subset of culture, could increase students' ability to convey and interpret meaning effectively in proper situations via textbooks. Then, EFL textbooks play a critical role in modern world of communication, and cultural aspects should not only be included in national level but also in global domain. So, in this regard, EFL textbooks need cultural assessment to know to what extent they meet the students' requirements and to pinpoint the absence of any cultural elements. Above all, another important issue that encourages us to run this assessment is that these books have not been assessed culturally since their publication. 


\section{3 Statement of the problem}

The relation between culture and language in general andEnglish as a foreign language in particular has reproduced much argument among the scholars. For some (e.g., McDervitt, 2004; Pulverness, 2003), language is interwoven with culture and any effort toward linguistic exchanges entails some kind of cultural knowledge. The awareness of culture integration into the foreign language contexts has consequently received a position through a paradigm shift from linguistic competence to communicative competence. The communicative period of language teaching make language learners' acquire new cultural settings. These settings are learned to reveal the target language culture and native speakers as the mere elements for the success of learners. In their extreme attitudes, communicative competence followers consider foreign language learning as no less than acculturation, asserting that learning another language is equal to changing in mind and body to understand and to be understood the foreign language (Bex, 1994). However, other scholars consider the issue of culture in language learning contexts with reasonable care. Aleptkin (2002) and Smith (1976) both support intercultural competence, which exceeds the constraints and limits of a typical native speaker. To some extent, this is partly because English language has been extended to worldwide lingua franca status, whose nonnative speakers have already been more than native speakers. Thus, the global use of the English language necessitates international cultural awareness rather than mere followers of the target language culture. In other word, it may be asserted that global communication through English is encouraged and involves primarily nonnative speakers' interactions, hence rejecting the need for a uniform native model.

Considering this view, McKay (2004) and Kachru (1986) states that English as an International Language necessities to refer to one's own culture and concerns to others instead of being merged to the culture of those who speak it. However, there is a question that whether or not it will be possible to learn English apart from culture. Fairclaough (1989) states that language is a dependent paradigmin a social institution that is generated by certain powers and structures shaping our functions in the society. Therefore, learning a foreign language is a specific way of conforming into a multifaceted system of classified proficiencies, thoughts, behaviors, modes of interaction of specific individuals.

There exist three categories of culture in textbook according to Cortazzi and Jin (1999). Three classes of cultural materials can be used in language textbooks and based on the objectives of the course and the needs of the students. 'Target cultural materials' commonly revolve around one or two target cultures, for example the United Kingdom or United States. The textbooks of this sort are commonly used in 
the EFL context.Although broadly practiced all over the world; they are under criticism for their cultural monopolization and profitability. 'Local cultural materials' belong to the textbooks that encompass language learners' culture and subcultures.They are often produced for a specific country. The educational goal of this kind of textbooks is to make learners to communicatewith foreigners about their own culture and national identityinstead of being prepared enough to confront with other cultures. 'International cultural materials' refer to the textbooks that contain worldwide cultures and subcultures that belong toboth English-speaking countries and also countries where English is learned as a second or foreign language. Cortazzi and Jin (1999) assert that the logic for this category of textbooks is that they use it in international situation.

\section{4 Related works}

In line with the above-mentioned studies, a study on cultural content analysis of high school English textbooks was done by Aliakbari (2004), and the results indicated that just a few superficial cultural contents were used in the books that are not sufficient in these series regarding the volumes.

In another study, Keshavarzand Akbari Malek (2009), investigated three aspects of meaning, namely social relations, subject positions, and contents, in the dialogues of advanced levels of two series of textbooks, namely Iran Language Institute and True to life textbooks, to reveal that whether there were any sensible ideological information in the two series considering a critical discourse analysis framework. The analysis indicated that in both series dialogues occur among those who have equal social status.Regarding subject position, analysis revealed that after friendsand occupation, commercial associated positions have the maximum frequency in the selected textbooks. Conversational content analyses demonstrated that topics mainly revolve around market and market related activities. It also concluded that a specific discourse type dominated the books.

Also another study was done by Khajavi and Abbasian (2011) to investigate cultural pattern of English language textbooks taught at Iranian High schools to see to what extent these materials are suitable in terms of national identity and globalization. Content analysis of textbooks revealed that textbooks are mostly neutral in terms of culture. Most of the texts had scientific subjects and also indicated the value of education. Regarding national history category, there is no reference to ancient history of the country. Belief and behavior part containing daily life is dominated in different parts of the books, and activities and passages related to national identity and international issues constitute less than $7 \%$ of the 
textbooks. As a result, these books were not appropriate for the age of globalization.

A critical assessment of the cultural content of two primary English textbooks used in Nigeria was done by Olajide (2010) based on Kilickaya and Ferit (2004) checklist since he believed that language textbooks should satisfy the cultural context in which they are going to be implemented. The relevant cultural content of each book was identified, analyzed and discussed. The summary of the findings indicated that the textbooks paid attention to how their cultural content controlled by both pupils and teachers, and fairly reflected the characteristics of learners in the cultural activities. Neither of the books referred to a target culture and irrelevant cultural content. The books were weak regarding the categorization of sociocultural elements categorization and contained neither negative nor positive comments on their cultural contents; however, there existed equally significant illustrations of the cultural contents.

A research done by Zareia G. R. and Khalessib M. (2011) set out to investigate cultural figures in the internationally distributed textbooks (IDTs) of the English Language, i.e., Interchange Series. A model of cultural patterns was expressed to analyze the contents of the books based on Williams' (1983) definition of culture. He believed that the ideas of culture comprised a number of values that are combined as certain norms to be run by institutions and also displayed as artifacts. The analysis revealed that value as one component comprised 'entertainment, liberal, consumerism, and inculcation of Western values'. Norm as another constituent included 'girlfriend-boyfriend relationship, opposite sex contact or dating, pet-keeping, and club-dancing'. The next type, i.e., institution involved 'entertainment, commercial, sports, educational, and conventional institutions'. The ten sub-categories of cultural artifact included 'occupation, clothes, name, music, sport, art, celebrity, food, instrument, and education. Broadly speaking, the results indicated that textbooks are artifacts, which are powerfully dealt with cultural assumptions and biases.

Rashidi and Heidari (2011) investigated the effect of teaching culturally based texts on thePersian English as a foreign language (EFL) learners' motivation and reading performance to know whether teaching the culturally-loaded texts to PersianEnglish for foreign language (EFL) learners have any impact on their performance on reading comprehension tests. To attain the purpose, 102 Persian EFL learners (belonging to two classes) were sampled, by means of convenient procedure of sampling. The experimental group was given the treatment (teaching culturally loaded texts). The results showed that teaching culture elements of target 
language can have a considerable influence on the performance of language learners regarding reading comprehension.

An Analysis of Local and Target Culture Integration in English Textbooks was done byAnggraini, Susanti and Syahri (2014) to find out the percentage of local culture integration and target culture integration in the selected English textbooks for senior high school in "English Zone" and "Interlanguage". This research design was a content analysis. The procedure of analyzing the data began by categorizing the data into local or target culture division then it was analyzed based on Byram's cultural content checklist (1993) while the pictures were simply classified into local culture or target culture. The results showed that the percentage of local culture integration in English Zone is more than in Interlanguagezone; whereas, the percentage of target culture integration in English Zone is less than in Interlanguage zone. Generally, both the percentage of local and target culture were very low regarding the checklist.

Since nowadays students confront with different situation both virtually in World Wide Web and really in different conferences and meeting, it is appropriate to be familiar with a wide range of cultural content at an international level in orderto be well-prepared to confront different situation.

Considering the above-mentioned points, the question arises that to what extend our English language textbooks meet one of the indispensable part of language that is culture. Since English language textbooks of high school (first three years) in Iran have been changed during last three years in order to meet the requirement of students, it is significant to find out how much national, international and target culturally familiar content is included in this book; likewise it could be helpful to give feedback to teachers, curriculum developers and those who are in charge of service learning in educational system.

\section{5 Research Questions}

1. To what extent do English language textbooks of grade 7, 8 and 9 in Iranian education uphold national cultural familiarity?

2. To what extent do English language textbooks of grade 7, 8 and 9 in Iranian education uphold international cultural familiarity?

3. To what extent do English language textbooks of grade 7, 8 and 9 in Iranian education uphold target cultural familiarity? 


\section{Methodology}

Byram's (1993) checklist was used in the procedure of content analysis. The checklist reveals the scope in which a textbook contains cultural content. Regarding the research questions, national, international and target cultural content of the textbooks were analyzed considering the following cultural contents;

Social identity and social group (social class, regional identity and ethnic minorities),

Social interaction (Differing levels of formality, Nonverbal language, Verbal Language, Greeting and Gender)

Belief and behavior (moral, religious beliefs and daily routines),

Social and political institutions (state institutions, health care, law and order, social security, local government, Community service, Business and industry)

Socialization and the life cycle (Family, School, Employment, Media, Ceremonies, Art, Food, Relationship and Sport),

National history (historical and contemporary events seen as markers of national identity)

National geography (geographical factors seen as being significant by members)

Stereotypes and national identity (what is "typical" symbol of national stereotypes, national identity, famous people, famous monuments and famous folktales)

(Byram, 1993, As cited in Juan, 2010, p.138).

Considering the checklist items, all of the content was analyzed in order to fit into this classification.Two raters analysiswere conducted to increase reliability and compatibility of one part of the book to an especial item in the checklist.

\section{1 Materials}

Three English language textbooks of grade 7, 8 and 9, which are recently being taught at high school level in Iran, were selected for analysis.

The list of the books is as follows:

Alavimoqadam, B., and et. al (2014). English for School Prospect Book 1. Student Book and Work Book, Tehran: TextbookPublishing Company of Iran.

Alavimoqadam, B., and et. al (2014). English for School Prospect Book 2. Student Book and Work Book, Tehran: Textbook Publishing Company of Iran.

Alavimoqadam, B., and et. al (2014). English for School Prospect Book 3. Student Book and Work Book, Tehran: Textbook Publishing Company of Iran. 


\section{2 Method of Analysis}

Content analysis method was conducted, and a coding scheme was designed according to items in the checklist. Each lesson consists of conversation, some practices, and language skillsthat were coded based on theme and meaning that were categorized into national, international and target culture. The number of codes was added up and then frequency and percentage of each code were calculated. Two raters analyzed the textbooks to increase the reliability of the analysis.

\section{Result}

The results of content analysis in Table 1 Shows that these books are nationalculture oriented and a few international cultural contents were used in these series, and almost no target cultural content was used. As the frequencies and percentages displayed, the largest parts of the textbooks were associated with socialization and life cycle part (36.94\%). Some subjects like family, School, media, ceremonies and art are covered in their lessons. After that, social interaction, such as nonverbal and verbal language and greeting (17.5\%), belief and behavior, such as moral and religious beliefs and also daily routines $(16.11 \%)$, social and political institution (12.22\%), national geography (8.33\%),stereo types and national identity (5.27\%), social identity and social group, such as social class, regional identity and ethnic minority $(2.5 \%)$ and the least amount was assigned to national history $(1.11 \%)$. Almost, no content contained culture-free materials and nearly more than $90 \%$ of the materials revolve around national cultural material, less than $10 \%$ of the content presents international cultural aspects and no material is related to target culture.

In line with the questions of the research put forward in the method, the result concerning the first question, that is to what extent do English language textbooks of grade 7, 8 and 9 in Iranian education uphold national cultural familiarity?,shows that these books almost completely presented national culture. Based on Byram's cultural content checklist (1993), more than $80 \%$ of cultural content was respectively related to socialization and life cycle, social interaction, belief and behavior and social and political institution and less than $10 \%$ was dealt with national geography, and also the remaining (10\%) referred to national, social and regional identity. It is indicated that there was no equilibrium in aspects of culture covered in this book since all aspects of cultural identity were poorly attended at the cost of paying more attention to socialization. 
Regarding the second question, To what extent do English language textbooks of grade 7, 8 and 9 in Iranian education up hold international cultural familiarity?, these books contained about $7 \%$ of international cultural content and were very weak in presenting custom, values and norms of other countries.

It is better not to answer the third question, To what extent do English language textbooks of grade 7,8 and 9 in Iranian education uphold target cultural familiarity?, since it is clear that less than one percent of the content was dealt with target cultural content. It is indicated that the authors of the three books intentionally left this part blank maybe for students not to be acculturated to western culture.

The overall results suggest that the junior high school English textbooks are locally cultural oriented since $92.22 \%$ of the cultural content in this series book is related to national culture and about 7\%to international cultural content and less than $1 \%$ to target culture. It also shows that this book is designed to make students prepare for presenting their cultural points; whereas, they have very weak knowledge of international cultural aspects and almost no knowledge of target culture to interact with people of other countries.

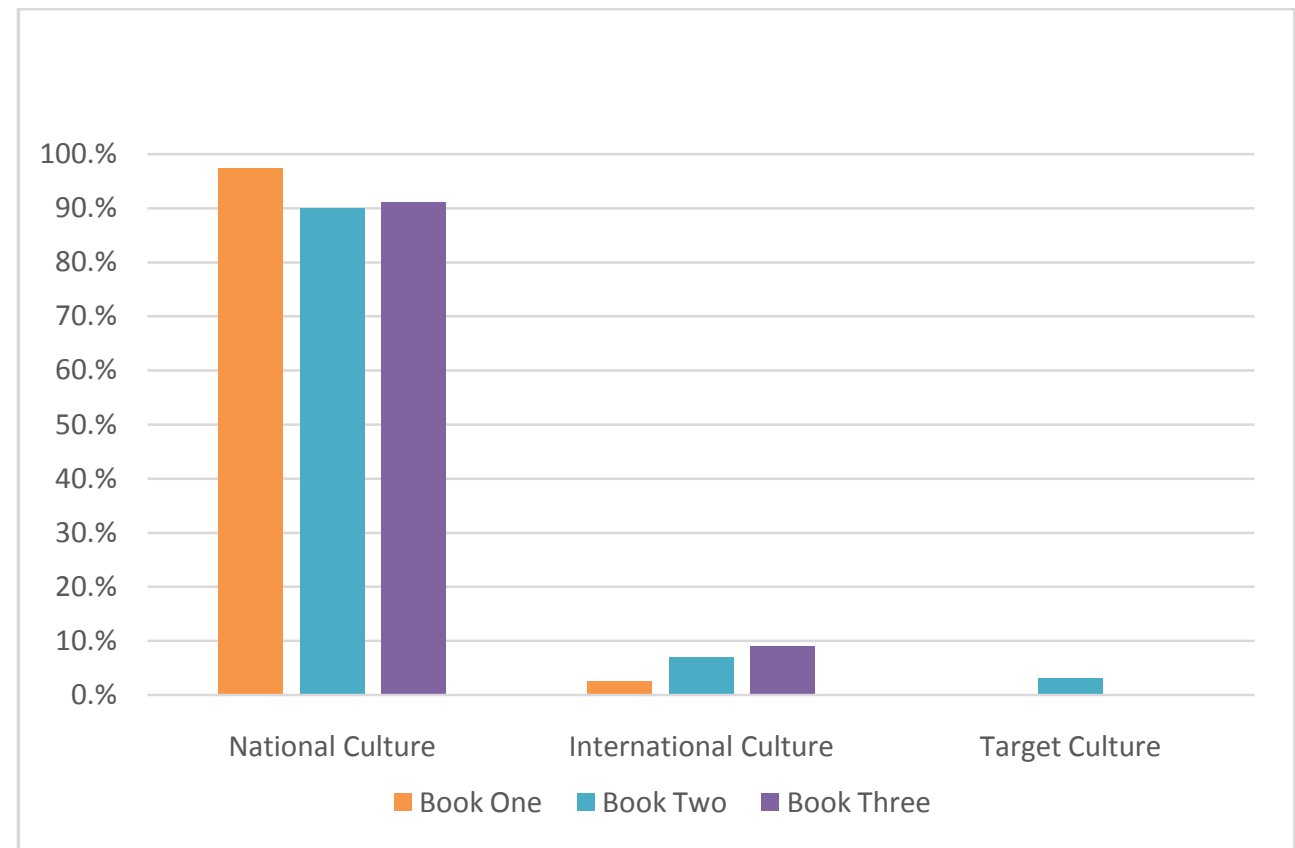

Fig.1. Percentage of National, International and Target Cultural content of English Language Textbooks of Grade 1, 2 and 3 in Junior High School 


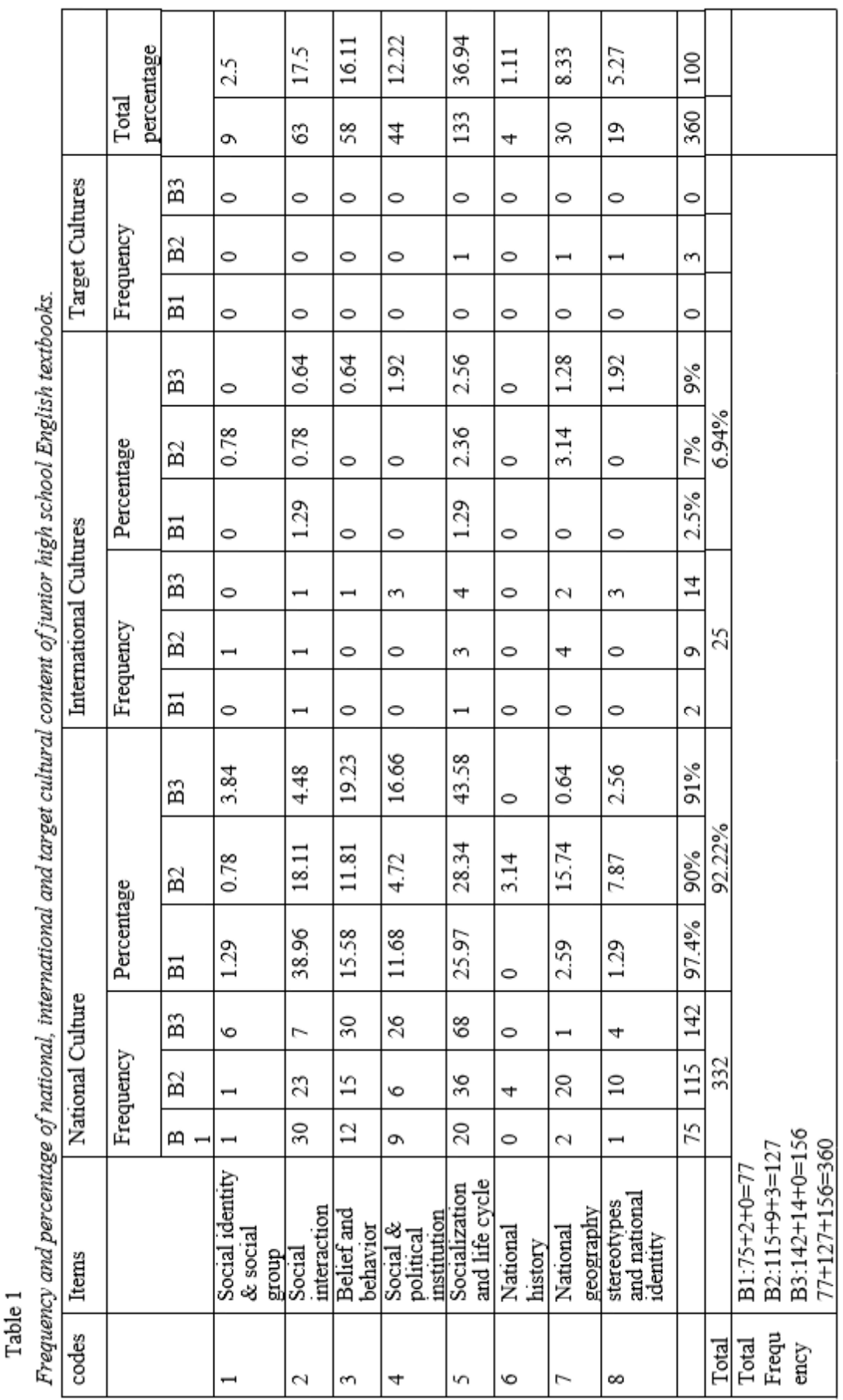




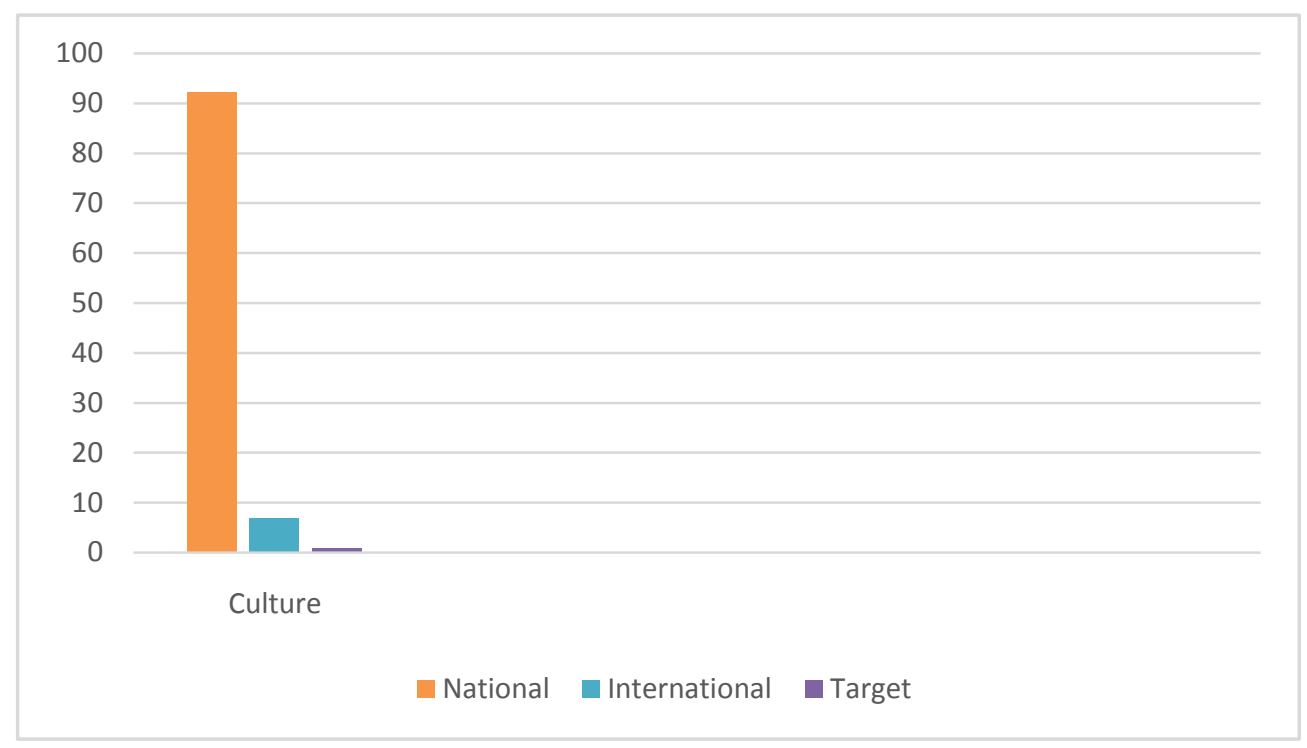

Fig.2. Percentage of National, International and Target cultural content in Junior High School English Language Textbooks

\section{Discussion}

The results of the study primarily showed that junior high school English language textbooks have been designed to get students familiar with their own culture in English language at the cost of paying little attention to international cultural points and almost neglecting target cultural content. Nearly most of the content is artificial and manipulated for this purpose intentionally since the authors want the students to be prepared to convey their own cultural points to peoples of other countries without any understanding about their cultural aspects.However even for this purpose, the equilibrium among the social identity, social interaction, national history, national identity and geography has not been observed. Since English language is used in international contexts for instance tourism industry, scientific and commercial affairs, and the development of the technology makes the world similar to a village for communicating via different multimedia like internet, social network and video conferencing, familiarizing students with cultural matters of other countries necessitates this mater.

This can be attributed to the fact that some authors believe that English converts to lingua franca and it should be learned in a culture-free context (Alptekin, 2005; Jenkins, 1996, 2000, 2002, 2005; Seidlhofer, 2001). Considering the findings and 
very low percentage of international cultural content, McKay (2004) and Kachru (1986) asserted that English as an International Language necessitates not only being familiar with one's own culture but also understanding other cultural facets of other foreign countries to communicate effectively.

The findings are also against Tomalin's (2008) view who believes that understanding other cultural norms and values as a fifth language skill is a must for communicating in globalized world.

Keshavarzand Akbari (2009) found a specific discourse dominancy to commercial affairmaking the books not to have a balance among other cultural context.Almost the same result was observed in the findings here since social, national and geographical identity were not presented well even in national cultural scope.

The results of this study are in line with the study previously published on junior high school English language textbooks in Iran regarding the extent of compatibility of cultural content to globalization and national identity showing the contentswere very weak in terms of familiarizing students with their national culture mostly national identity and international cultural points in age of globalization (Khajavi and Abbasian, 2011).

A critical assessment of the cultural content of two primary English textbooks done in Nigeria by Olajide (2010) based on Kilickaya (2004) checklist were in line with our findings since they believe that language textbooks should satisfy the national cultural context and none of the books supported target culture and irrelevant cultural content. The books also were very weak regarding the balance among socio-cultural elements.

A research done by Zareia and Khalessib (2011) was against our finding since those book were designed based on target cultural customs, norms and values that it encompasses a large amount of cultural biases in western countries specially United States; whereas, in these books target cultural content, specially socialization and life cycle in national level,was discussed.

An analysis of Local and Target Culture Integration in English Textbooks done by Anggraini, Susanti and Syahri (2014) was compatible with our finding since the results showed that the percentage of target culture was very low regarding the checklist.

To sum up the point, the findings in most of the researches showed that there is no equilibrium between local, international and target cultural contents in most of the books specially the case of this study. Since English language is used in 
international context, knowing other cultural content could help have effective bilateral communication via different media and medium.

\section{Conclusion}

Considering cultural aspects of these EFL textbooks in the above checklist, the findings of this evaluation shows that students' requirements are not met in modern world of communication. The results of the study indicates that these series books are local-cultural oriented for the purpose of making students ready to convey their own culture to foreigners without any understanding about other people's cultural points in English language whereas the ability for effective communication needs mutual understanding of cultural aspects both in national and international level; moreover, the balance between those cultural aspects mentioned in the table was not observed even for local cultural aspects, Since little attention was paid to national identity, history and geography of students as well as their social, regional identity and social and political institution, students have weak understanding of the whole aspects of their own cultural background to confront with foreigners in different types of communication.Additionally,all elements of cultural aspects of language in international and target levelin these book series are nearly ignored at the cost of paying more attention to some elements in national levels, such as beliefs, behavior and lifecycle.These findings have important implications for syllabus designers to incorporate national, international and target cultural context to augment students' cultural familiarity for effective communications. In addition, teachers can get benefit from the findings to focus more on some missed elements, and include some supplementary tasks and assignments to make students familiar with different contextsboth in local and global setting.

\section{References and notes:}

Alptekin, C. (2002). Towards intercultural communicative competence in ELT. ELT Journal 56/1: 57-64.

Aliakbari, M. (2004). The Place of Culture in the Iranian ELT Textbooks in High School Level. 1-14.The 9th PanPacific association of Applied Linguistics Conference, Korea.

Alptekin, C. (2005). Dual language instruction: Multiculturalism through a lingua franca. TESOL Symposium on Dual Language Education: Teaching and Learning Two Languages in the EFL Setting. September 23, 2005. Bogaziçi University, Istanbul, Turkey.

Alavimoqadam, B., \& Et. al (2014). English for school prospect book 1, 2 and 3 student books and work books, Tehran: Textbook Publishing Company of Iran.

Brown, G. (1990). Cultural Values: The Interpretation of Discourse. ELT, (1): 11-17.

Brown, H. D. (1994). Principles of language learning and teaching (3rd ed.). Englewood Cliffs, NJ: Prentice Hall Regents. 
Bex, A. R. (1994). The Problem of Culture and English Language Teaching in Europe. IRAL, 32(1), PP. 57-67.

Byram, M. (1993). Language and culture: Theneed for integration. In M. Byram (Ed.),Germany: Its representation in textbooks forteaching German in Great Britain (pp. 3-16)Frankfurt: Diesterweg

Byram, M.,\&Fleming, M. (Eds.) (1998). Language Learning from an Intercultural Perspective. Cambridge: Cambridge University Press.

Cortazzi, M., \&Jin, L. (1999). Cultural mirrors,materials and methods in the EFL classroom.In E. Hinkel (Ed.), Culture in second languageteaching and learning. Cambridge:Cambridge University Press.

Canagarajah, A. S. (1999). On EFL Teachers, awareness, and agency. ELT Journal, 53(3), 207-214.

Fairclough, N. (1989). Language and Power. Essex: Blackwell.

Jenkins J. (1996). Native speaker, non-native speaker and English as a Foreign Language: time for a change. IATEFL Newsletter, 131:10-11.

Jenkins J. (2000). The Phonology of English as an International Language. Oxford: Oxford University Press.

Jiang, W. (2000). The relationship between culture and language. ELT journal, 54(4), 328334

Jenkins, J. (2002). A sociolinguistically based, empirically researched pronunciation syllabus for English as an international language. Applied Linguistics, 23(1), 83-103

Jenkins, J. (2005). ELF at the gate: The position of English as a lingua franca. HumanizingLanguage Teaching, 7(2). Retrieved February 23, 2006, http://www.hltmag.co.uk/mar05/idea.htm

Juan, W. (2010). A Content Analysis of the Cultural Content in the EFL Textbooks. Canadian Social Science, 6(5), 137-144.

Gao, F. (2006). Language is culture: On intercultural communication. Journal of Language and Linguistics, 5(1), 58-67.

Gurkan, S. (2012). The Effects of Cultural Familiarity and Reading ActivitiesonL2 Reading Comprehension. Procedia-Social and Behavioral Sciences 55, 1196 - 1206.

Ganjabi, M. (2014).The Effect of Cultural Familiarity on the Iranian Language Learners' Performance and Use of Cognitive and Metacognitive Strategies in Reading Comprehension. International Journal of Language Learning and Applied Linguistics World, 5(4),79-90.

Kachru, B. (1985). Standards, codification and sociolinguistic realism: The English language in the outer circle. In R. Quirk \& H. G. Widdowson (Eds.), English in the World:TeachingandLearning the Language and Literature, 11-30.

Cambridge,England: Cambridge University Press.

Kachru, B.(1986). The Alchemy of English. USA: University of Illinois Press.

Kachru, B. (1986). The Power and Politics of English. World Englishes, 5, 2(3), 121-140.

Kachru, B. \& Nelson C. L. (1996). World Englishes. In S. L. McKay and N. H. Hornberger (Eds.), Sociolinguistics and language teaching, 71-102. Cambridge: Cambridge University Press.

Kramsch, C. \& Sullivan P. (1996). Appropriate pedagogy. ELT Journal,50(3), 199-212 
Kilickaya, F. (2004). Guidelines to evaluate cultural contents in textbooks. The Internet TESL Journal, 12, http://itesl.org/techniques kilickaya-cultural content.

Keshavarz, M.H., \& Akbari Malek, L. (2009). Critical discourse analysis of ELT textbooks. The Iranian EFLJournal, 5, 6-19.

Khajavi, Y. and Abbasian, R. (2011). English Language Teaching, National Identity and Globalization in Iran: the Case of Public Schools. International Journal of Humanities and Social Science, 1(10), 181-186

McKay, S. L. (2003). The cultural basis of teaching English as an international language. TESOL Matters, 13(4), 1-6.

McDevitt, B. (2004). Negotiating the Syllabus: A win-win Syllabus. ELT Journal, 58(1), 39.

McKay, S.L. (2004). Western Culture and the Teaching of English as an International Language. English Teaching Forum Online, 42(2), 10-14.

Mckay, S. L. (2004). Toward an appropriate EILpedagogy: Re-examining ELT assumptions.International Journal of Applied Linguistics,13(1). Retrieved from http://people.ufpr.br/ clarissa/pdfs/EILpedagogy_McKay.pdf

Olajide S. B. (2010). A Critical Assessment of the Cultural Content of Two Primary English Textbooks Used in Nigeria. Journal of Language Teaching and Research, $1(5), 656-661$

Pulverness, A. (2003). Distinctions \& Dichotomies: Culture-free, Culture-bound. Available: http://elt.britcoun.org.pl/forum/distanddich.htm.

Rashidi N. \&Heidari K. (2011). The Effect of Teaching Culturally-Based Texts on the Persian English as a Foreign Language (EFL) Learners 'Motivation and Reading Performance. Journal of Languages and Culture, 2(8), 141-147.

Smith, L. (1976). English as an international auxiliary language. RELC Journal, 7(2), 3843.

Seidlhofer, B. (2001). Closing a conceptual gap: the case for a description of English as a lingua franca. International Journal of Applied Linguistics, 11(2), 133-58.

Sorongan D. A., Susanti R. \&Syahri I. (2014).An Analysis of Local and Target Culture Integration in English Textbooks. Lingua, Journal Bahasa \& Sastra, 15(1), 29-34.

Tylor, E. B., (1871). Primitive Culture: Researches into the Development of Mythology, Philosophy, Religion, Art, and Custom, U.K.: Oxford University Press

Tomalin, B. (2008). Culture: The fifth language skill, Viewed 13 January 2016 http://www.teachingenglish.org.uk/think/articles/culture-fifth-language-skill

Williams, R. (1983). Keywords: A vocabulary of Culture and Society (Rev. Ed.), New York: Oxford UP

Wei, Y. (2005). Integrating Chinese culture with TEFL in Chineseclassroom.Sino-US English Teaching, 2(7), 55-58.

Zareia G. R. \&Khalessib M. (2011). Cultural Load in English Language Textbooks: An Analysis of Interchange Series.Procedia-Social and Behavioral Sciences, 15 (2011), 294-301. 


\title{
Summary
}

\section{English Language Textbooks in EFL Education: Do They Improve Students' National, International and Target Culture Familiarity?}

\author{
Reza Abbasian \\ Islamic Azad University, Izeh Branch, Khuzestan, Iran
}

\author{
Reza Biria \\ Islamic Azad University, Isfahan (Khorasgan) Branch, Isfahan, Iran
}

The purpose of the present study was to evaluate English language textbooks of grade 7, 8 and 9 in theIranian Pedagogical curriculum to see to what extent students are exposed to national, international and target cultural familiar content in their classes. As Gurkan (2012) and Ganjabi (2014) say students who are familiar to cultural content of the target language have better reading comprehension scores than those who lack familiarity to target language cultural content. Since culturally familiar content of language in international and target level increases learners' comprehension almost in all skills, textbooks are one of their real manifestations in curriculum. The study also intended to investigate how the content of English textbooks represents national, international and target culturally familiar content for students to be well-prepared to convey their own culture to foreigners as well as to be acquainted with other cultures that they have contact with for any means anywhere in the virtual and real places.Content analysis method was used and a coding scheme was designed according to items listed in Byram'scultural content checklist (1993). The findings of this qualitative study showed that ELT textbooks covered a restricted range ofinternational cultural content as well as target cultural content; moreover, the result revealed that just restricted amount of national culturally familiar content are applied in the English language textbooks. Based on the results of the study, some directions would be suggested to be appliedin the English language syllabus; moreover, the results can be used by teachers as a direction for adding some supplementary and complementary materials to develop English language textbooks in education for effective communication.

Keywords: Cultural familiarity, English language textbooks, National and international cultural content 